\title{
Horse breeding of the Kaliningrad region: state and development prospects
}

\author{
Tamara Antunovich* and Vasily Verkhoturov \\ Kaliningrad State Technical University, 236022, Kaliningrad, Russia
}

\begin{abstract}
The article discusses the development of horse breeding in the Kaliningrad region. The materials are based on the analysis of the history of development and the current state of the main directions of horse breeding in the Kaliningrad region. The paper presents statistical data on the number of horses of different periods, analyzes historical information and the current state of horse breeding. Breeding achievements, problems and prospects for the development of horse breeding in the Kaliningrad region are discussed within the framework of the state strategy for the development of the industry in the Russian Federation.
\end{abstract}

For the Kaliningrad region, the main factor determining the sustainable development and level of competitiveness of agricultural enterprises is their geographical location. An important strategic direction for the development of the Kaliningrad region is the production of ecologically clean agricultural products and the active development of agritourism with the attraction of tourists from Russia and Europe [1,2]. Horse breeding has always occupied a special position among other branches of animal husbandry [3]. This area included many important aspects of life: sports, cultural and entertainment, economic, military, and others. Research to assess the number of horses, ways and prospects for the development of horse breeding in the Kaliningrad region - a unique and isolated region of the Russian Federation, is relevant.

The purpose of this work is to conduct a retrospective study of horse breeding on the territory within the modern borders of the Kaliningrad region, to identify the stages of development of horse breeding and to assess the change in the number of livestock and the prospects for horse breeding.

Research methods and materials: historical, zooengineering, statistical, analysis of observations and available archival data.

Today, horses in Russia are bred mainly in those regions where peoples who previously led a nomadic lifestyle live, for whom horse breeding and sheep breeding remained the main directions in animal husbandry.

This article focuses on the Soviet and post-Soviet period of the development of horse breeding, despite the fact that this branch of animal husbandry was of particular importance in East Prussia. Horse breeding in the Kaliningrad region dates back to 1951, at that time the number of horses in the region was maximum - more than 30 thousand

\footnotetext{
* Corresponding author: toma.equivet@gmail.com
} 
heads. In recent decades, the share of horse breeding in the region has significantly decreased and amounts to, on average, 2 thousand head of horses.

One of the main indicators of the importance of horse breeding in the livestock sector of the region is the number of horses, which changes in accordance with the ongoing social and socio-economic processes in Russia and the region. According to the data of the territorial body of the Federal State Statistics Service for the Kaliningrad Region, in 2020, the Kaliningrad Region contains 2.23 thousand horses in farms of all categories, including 1.43 thousand horses are kept in household farms; 0.25 thousand - peasant (farmer) households and individual entrepreneurs; 0.55 thousand - agricultural organizations.

The breed composition of horses in the Kaliningrad region is diverse. Among the total massif such breeds can be distinguished as Hanoverian, Holstein and Trakehner breeds. Among the total number of horses, the number of outbred animals prevails over the number of purebred animals / This is due to the fact that the survey took into account the horses kept in farms, stud farms and other enterprises that have statistical data.

The dynamics of the number of horses in the Kaliningrad region in the period from 2000 to 2020 is shown in the graph (Fig. 1).

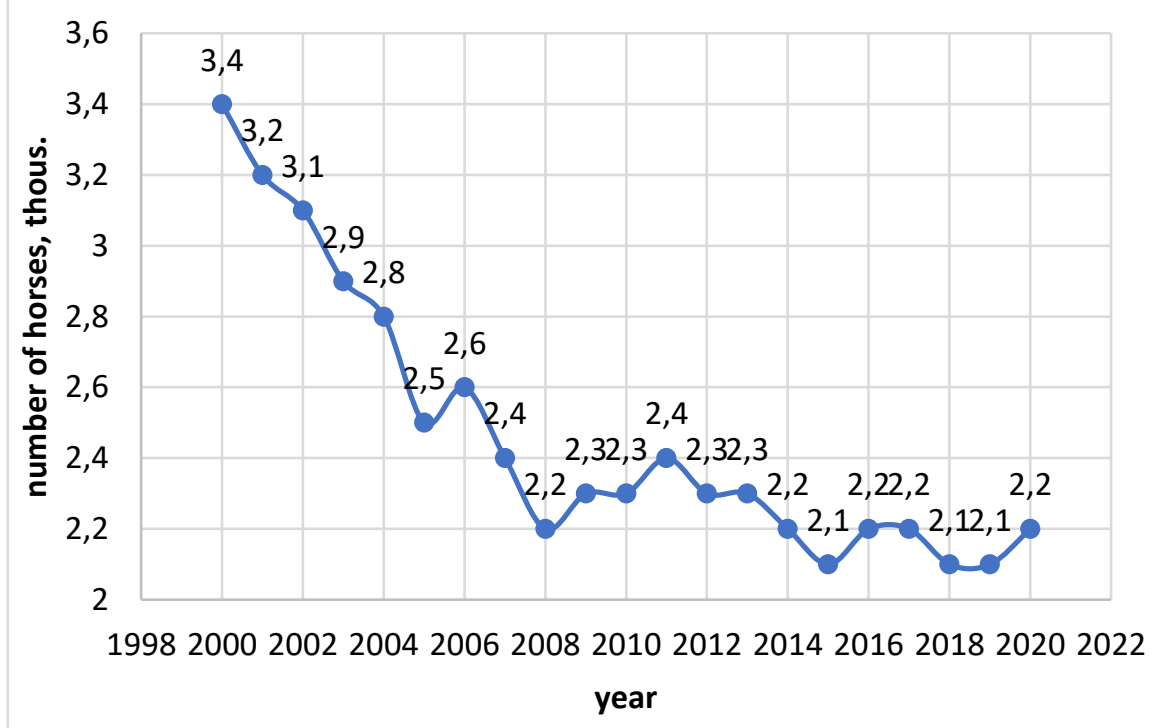

Fig. 1. The number of horses in the Kaliningrad region in 2000-2020, thous.

The number of horses in the Kaliningrad region from 1951 to 2020 decreased 6 times, from 31,100 to 2200 heads. The reasons for the extremely sharp reduction in the number of horses in the region are due to many factors, including the absence of a state (and regional) program for the development of the industry, a decrease in funding and ineffective breeding work. Obviously, all this had a detrimental effect on the development of the industry. Most of the stud farms were liquidated, the area of fodder resources was reduced, the material and technical base deteriorated. Unfortunately, due to the forced slaughter, some horse breeds were on the verge of extinction (Russian horse breed). The creation in 1965 of the Main Directorate of Horse Breeding and Horse Breeding under the USSR Ministry of Agriculture, at the expense of administrative and financial support, made it possible to support the industry. Thanks to this, a breeding center for pedigree horses was created in the Kaliningrad region - the Georgenburg stud farm (Chernyakhovsk). The stud farm breeds 
horses of the Hanoverian, Holstein and Trakehner breeds. The modern history of the stud farm began in 2002, when the company returned to its famous name, which gained fame "Georgenburg". For several years there has been an active restoration of the buildings of the stud farm after a severe fire that occurred in 1997. Structures of stables, riding halls, hotel have been restored in accordance with their historical appearance.

At present, the territory of the Georgenburg stud farm is more than 2.5 hectares. The material and technical base includes: a complex of horse-breeding buildings designed for keeping more than 300 horses; springarten - a construction for training the jumping qualities of a horse; jumping field with modern soil; two indoor arena - training and exhibition, equipped for competitions in dressage and show jumping, as well as various auxiliary buildings. The old stables, preserved from German times, have been reconstructed taking into account all modern requirements for keeping horses.

The main important task that the Georgenburg specialists set themselves is the breeding and training of high-level sports horses of the most popular horse breeds - Hanoverian and Holstein [4]. It is possible that in the future, work will continue on breeding and selection of the Trakehner breed. The federal program for the development of sports in the Russian Federation promotes the breeding of thoroughbred sports horses with an excellent conformation and capable of fulfilling all the requirements for Olympic equestrian sports. $o$ conduct breeding work at the plant, several stallions of the required class and genealogical complex are used. It is obvious that the enrichment of the population's gene pool is carried out, among other things, thanks to the attraction of foreign high-class stallions-breeding (Grandville - a bay stallion of the Hanover breed, Coyote Agli - a black stallion of the Holstein breed, Highlander - a chestnut stallion of the Holstein breed). For a long time they were the leading producers of the stud farm and left behind a rich offspring.

It should be noted that in 2004-2005, in the practice of the stud farm, artificial insemination of mares was carried out. Materials for this procedure were purchased from the legendary stud farm Spree, the homeland of champions of big sports. Among the offspring obtained from artificial insemination was the Chicago stallion from Chicos Boy. He demonstrated the excellent qualities of a dressage horse and was also used as a breeder. Currently, the main producers in the stud farm are: the red stallion Respect of the Hanoverian breed; red stallion Kulano of Westphalian breed, which has full German origin; bay stallion Dantander Hit of the Hanoverian breed and a young gray stallion Kovcheg of the Hanoverian breed. The zootechnicians of the stud farm expect the first offspring from the stallion Kovcheg in 2021. Many years of experience in breeding and keeping horses in the conditions of the Kaliningrad region brings obvious results - thoroughbred horses from Georgenburg can be found today not only in Russia, but also in European countries.

On the territory of the Kaliningrad region there is a Private Stud Farm "Weedern", which is located in the Ozersk region. This stud farm specializes in breeding the Hanoverian horse breed. The total area of the agricultural complex is 5.5 thousand hectares. "Weedern Private Stud Farm" became the second breeding reproducer in Russia for the Hanoverian horse breed. The history of "Weedern" dates back to the early 18th century, but the restoration of the former manor began in the early 2000s, when the reconstruction of the historical buildings of the stud farm began. 


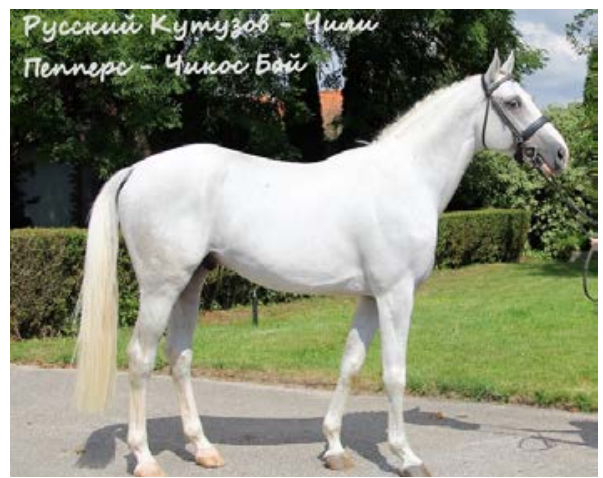

Fig. 2. Stallion Kovcheg, producer of the “Georgenburg” Stud Farm.

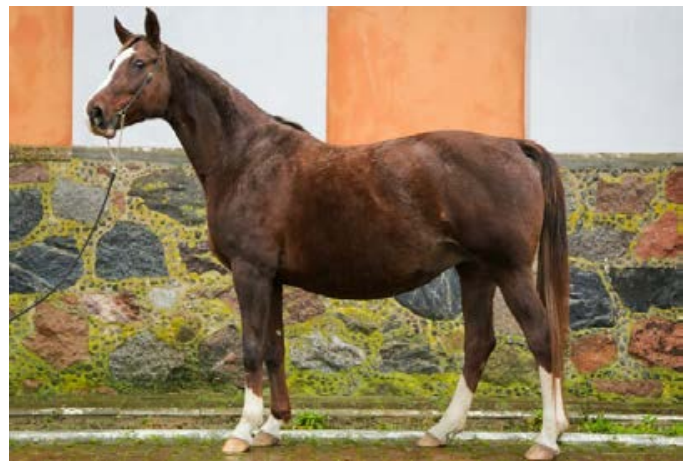

Fig. 3. Mare Watervita, mother of the "Weedern" Private Stud Farm.

Interestingly, the Weedern stud farm is famous for its broodstock. More than 15 female mares are included in the book of the Hanoverian Union of Germany. Recognition and respect from foreign specialists is confirmed by the fact, that the horses of the stud farm, in addition to the Russian breeding passport, also receive the passport of the Hanoverian horse of Germany. So, mare Watervita, red, 2007 year of birth. Water Prince - Widnaya. Her father, the stallion Waterprinz from Waterpass and Paprika. Her mother, a mare Widnaya, belongs to the Griffs-Tochter family. From this family came 4 stud stallions, as well as international dressage horses (Table 1). Members of this family have productive movements (Fig. 2,3).

Table 1. Description of pedigrees.

\begin{tabular}{|c|c|c|c|}
\hline \multicolumn{4}{|c|}{ Pedigree of the mare Waterwita } \\
\hline \multirow[t]{4}{*}{$\begin{array}{l}\text { Waterwita } \\
\text { mare, red, } 2007\end{array}$} & \multirow[t]{2}{*}{$\begin{array}{l}\text { Waterprinz, red, } \\
2003\end{array}$} & $\begin{array}{l}\text { Waterpass, } \\
\text { chestnut, } 1997\end{array}$ & \multirow{4}{*}{$\begin{array}{l}\text { The mare Vidnaya belongs to the family } \\
\text { Griffs-Tochter (Griffs-Tochter). From } \\
\text { this family came } 4 \text { stallions-producers, } \\
\text { as well as horses of international class in } \\
\text { dressage. Representatives of this family } \\
\text { have productive movements. }\end{array}$} \\
\hline & & $\begin{array}{l}\text { Paprika, } \\
\text { chestnut, } 1992\end{array}$ & \\
\hline & \multirow[t]{2}{*}{ Widnaya, 1986} & $\begin{array}{l}\text { Wandal, } \\
\text { chestnut, } 1989\end{array}$ & \\
\hline & & $\begin{array}{l}\text { Daugava, red, } \\
1997\end{array}$ & \\
\hline \multicolumn{4}{|c|}{ Pedigree of the stallion Kovcheg } \\
\hline \multirow{4}{*}{$\begin{array}{l}\text { Kovcheg, } \\
\text { stallion, grey, } \\
2016\end{array}$} & \multirow{2}{*}{$\begin{array}{l}\text { Russkiy Kutuzov, } \\
\text { grey, } 2012\end{array}$} & Cashas, grey & \multirow{4}{*}{$\begin{array}{l}\text { The mare Chili Peppers belongs to the } \\
\text { famous Cor de la Briere line, to the } \\
\text { Griffs Tochter family. } \\
\text { Cor de la Briere is an outstanding stud } \\
\text { breeder who has left numerous, famous } \\
\text { descendants. He consistently transmitted } \\
\text { his unique technique and jumping power. } \\
\text { Cashas - he is the son of Caretino, whose } \\
\text { offspring have earned more than } 3 \\
\text { million euros in total. }\end{array}$} \\
\hline & & $\begin{array}{l}\text { Una, chestnut. } \\
2004\end{array}$ & \\
\hline & \multirow[t]{2}{*}{$\begin{array}{l}\text { Chili Peppers, } \\
\text { chestnut, } 2007\end{array}$} & $\begin{array}{l}\text { Chicos Boy, } \\
\text { chestnut, } 2000\end{array}$ & \\
\hline & & $\begin{array}{l}\text { Panda, chestnut, } \\
1993\end{array}$ & \\
\hline
\end{tabular}


Mare Doveriya - bay, 2009, from Drongo and Werf. A large, pedigree mare in the type of a modern sports horse. Her father, Drongo, from Disput and Gortenzia, was used as a stud stallion at the Weedern stud until 2013. The origin from the maternal side of Doveriya is valuable, the mare must be used in breeding work. Mother, mare Werf, from the Wolshebnik and Flavia, bred from Germany, daughter of Furstenfels and Weshuna. Feiner Kerl line Mare Raissa - dark bay, born in 2001 (Rubiloh - Irwana-Rudiloh), Westphalian, Hanoverian Arma's family.

Raissa's mother, mare Irwana, Hanoverian breed born in 1992. from Interpol and Welfgunda. Interpol is a dressage stallion, derived from the Anglo-Arabian Ihschallah, a unique stud stallion recognized by all leading German unions, Hanover, Oldenburg, Trakehner, etc. The Arma family, to which Raissa belongs, has more than 20 mares awarded the State Prize of the Union, 40 horses have competed in classic equestrian sports, show jumping and dressage, and the stallion-producer Frenchman I with a training index of $122 \%$ is licensed by the Bavarian and Hanover Unions of Germany.

At the stud farm, Raissa was given offspring, the quality of which the mare was rated at 9 points. The mare herself showed high performance ratings, and is able to pass them on to her offspring. Her two daughters are enrolled in the production team.

The main producer of the stud farm "Weedern" since 2000 was a black stallion of the Wasensee, with breaks in 2003-2009, when the stallion actively competed in competitions. During this time, the plant received 18 stallions and 16 mares. Wasensee (Walchensee) Weltmeyer-Bolesia-Brentano II, of the Feiner Kerl line, derived from Germany. In 1999, he was licensed by the Hanoverian Union of Germany based on the results of his performances in equestrian sports under the saddle of N. Menkova. Since 2015, the stud's producers have been the Hanoverian bay stallion Dantander Hit and the grey Trakhenen stallion Araratas, whose sire the stallion Abdullah was the Olympic champion in the team show jumping event in 1984. The main specialization of the horses of the stud farm is dressage. However, with specialized training, horses successfully show themselves in show jumping. The characteristics of the horse population in the districts of the Kaliningrad region are presented in table 2.

Table 2 Characteristics of the horse population in farms of all categories of municipalities of the Kaliningrad region for 2020.

\begin{tabular}{|l|l|c|c|}
\hline № & City districts of the Kaliningrad Region & $\begin{array}{c}\text { Number of horses } \\
\text { (heads) }\end{array}$ & $\begin{array}{c}\text { Horse density } \\
\text { (head/km2) }\end{array}$ \\
\hline 1 & Kaliningrad & 18 & 0,080 \\
\hline 2 & Bagrationovsky & 128 & 0,126 \\
\hline 3 & Gvardeyskiy & 59 & 0,075 \\
\hline 4 & Gurjevskiy & 184 & 0,135 \\
\hline 5 & Zelenogradskiy & 162 & 0,080 \\
\hline 6 & Krasnoznamenkiy & 328 & 0,256 \\
\hline 7 & Nemanskiy & 23 & 0,033 \\
\hline 8 & Nesterovskiy & 106 & 0,099 \\
\hline 9 & Ozyorskiy & 338 & 0,390 \\
\hline 10 & Pionerskiy & 1 & 0,121 \\
\hline 11 & Polesskiy & 43 & 0,052 \\
\hline 12 & Pravdinskiy & 126 & 0,097 \\
\hline 13 & Svetlovskiy & 13 & 0,162 \\
\hline 14 & Slavskiy & 333 & 0,247 \\
\hline 15 & Svetlogorskiy & 11 & 0,331 \\
\hline 16 & Chernyachovskiy & 221 & 0,172 \\
\hline
\end{tabular}


In many farms with different forms of ownership, horse breeding is being revived, which simultaneously solves several production tasks: horses - transport (working) means; horses as a productive animal; the use of horses for the organization and development of equestrian sports and equestrian tourism. The table shows that the number and density of horses in the Kaliningrad Region is concentrated in the Ozyorsky, Krasnoznamensky and Slavsky districts, which stand out significantly among others. It should be noted that historically, the south-east of the region is characterized by a larger number of horses than in other parts of the region (Chernyakhovsk). In terms of density, the Ozyorsky district is the leader, in general, an increased density is observed in the north-east of the region, and in the north-western part (Svetlogorsk).

It is obvious that the horse breeding industry of the Kaliningrad region has faced wellknown problems: weak material, technical and informational support; lack of highly qualified personnel; insufficient development of the racetrack infrastructure for conducting system tests, taking into account the requirements of the organization of the horse sweepstakes; lack of a unified system of control and quality management of breeding work; insufficient number of breeding horses. For the development of organizations engaged in breeding horses, it is necessary to maintain the provision of state support in the form of subsidies for the reimbursement of part of the costs associated with the conduct of breeding events $[5,6]$.

Horse breeding was once the most important area of domestic animal husbandry, including in the Kaliningrad Region. All industries were actively developing, starting with trotting horse breeding and ending with commodity breeding. Due to objective and subjective reasons, over the past century, horse breeding in the Kaliningrad Region has transformed into one of the most inconspicuous and insignificant branches of agriculture. It should be noted that in the Kaliningrad region, as part of the strategy for the development of horse breeding in the Russian Federation, it is advisable to form a competitive and efficient industry that will contribute to the preservation and improvement of the gene pool of horse breeds bred in the country, and increase their competitiveness in the domestic and global markets, as well as to solve the financial, economic and social problems of the region.

\section{References}

1. A.B. Sebentsov, V.A. Kolossov, M.V. Zotova, Vestnik Moskovskogo Universiteta, Seriya 5: Geografiya, E 4, 64-72 (2016)

2. A.B. Sebentsov, M.V.Zotova, Baltic Region, E 10(1), 89-106 (2018)

3. A.M. Sologubov, Bul. Baltic federal university, E 12, 68-75 (2012)

4. I.A. Koriugina, Y.V. Tarasova, N.V. Trushina, Horse breeding and equestrian sports, E 2, 9-10 (2011)

5. A.V. Artemova, E. N. Chingina, E-Scio, E 4, 21-26 (2020)

6. M. V. Noskova, M. S. Arkhilaeva, Bulletin Altai Stat. Agr. Univer., E 12, 98-103 (2009) 